\title{
Markers of the affecting model in contemporary political media communication
}

\author{
Elena B. Ponomarenko - Marina R. Zheltukhina - Gennady G. Slyshkin - \\ Liudmila A. Borzykh - Conchita García Caselles
}

\section{DOI: $10.18355 /$ XL.2017.10.04.06}

\begin{abstract}
The political and socio-economic situation in society produces certain conditions for a successful or unsuccessful political media communication flow. Mass media influence the socio-economic and political life of the country. Media discourse mirrors socioeconomic and cultural relations within and between states and defines the interests of the contemporary society. Institutional, stereotypical and mythological markers of the affecting model in today's political media communication are identified in this article within the framework of the discourse and the influence theories. In the article is established that the political language of the mass media reveals the peculiarities of linguistic consciousness, mentality, individual and mass speech behavior reflecting the institutional, stereotypical and mythological markers of the reactive model in the contemporary political media communication.
\end{abstract}

Key words: institute, stereotype, myth, markers, affecting model, influence, political media communication, media discourse

\section{Introduction}

The XXI century displays an exacerbation of the global socio-political situation, its active coverage in international and local mass media and, consequentially, an increasing interest of native speakers belonging to different linguistic cultures in its relation. Contemporary linguistics broaches an issue of the interaction between the addresser and the addressee, discourse and power, and tries to answer the questions regarding the role of the language in the permanent struggle of people for power and influence, including the political language of the mass media. The socio-economic and political environment in a state establishes certain conditions for a successful or unsuccessful political media communication flow. The political media discourse reflects socio-economic and cultural relations within and between states and defines the political and economic interests of the contemporary society (Zheltukhina 2003; 2015; Zheltukhina, Vikulova, Slyshkin, Vasileva 2016, Khrulyova, Sakhieva, 2017; Kong, Kayumova, Zakirova, 2017; Masalimova et al., 2017).

The information-oriented society is characterized by the increasing managerial importance of the mass media, which are a part of public relations, as well as increasing public awareness, free access to information, an unimpeded operation of all the mass media, availability of mass technical means which make information approachable to the majority of citizens (Karpukhin, Makarevich 2001; Levina et al., 2017). The locomotive power of the socio-economic and political change is at present the information environment, information technologies, nevertheless there is a dislocation towards the sphere of influence on people, to the sphere of "people manipulation by people" (according to K. Marx), which earns the status of totalitarian process in political media communication. The political media communication performance resides in formation of the ideological majority (political, religious, consumer, artistic, etc.) and achievement of a social harmony. 


\section{Theoretical research base: condition of problem's study}

The modern political media discourse is irrational and emotional and is characterized by prejudgment, subjectiveness, evaluativity and affective disposition. Even the texts of the news, by default purporting to be impersonal and objective, are fundamentally formulated within a certain ideological frame of interpretation (Hacker 1996; Fiske 1993). Put it otherwise, the informative and suggestive nature of the political media discourse are tightly intertwined and mutually conditioned. Thereby it is possible to speak not so much about the information pattern as about the affecting model within the "person - political media scene" system. A person represents two aspects within the political media scene: an addresser, which creates and transfers a message, i.e. an informing and affecting part (politician or journalist), and the addressee, who is conceiving a message, is individual and mass scale, direct and indirect (politician, journalist, electorate) (Slyshkin 2007; Ponomarenko 2013a,b,c; Garsiya-Kaseles, K. 2015a,b,c; Zheltukhina 2014; 2015; Zheltukhina, Krasavsky, Slyshkin \& Ponomarenko 2016; Zheltukhina, Krasavsky, Ponomarenko, Aleshchanova, Pavlov 2016; Zheltukhina, Slyshkin, Ponomarenko, Busygina, Omelchenko 2016; Zheltukhina, Vikulova, Serebrennikova, Gerasimova, Borbotko 2016; Zheltukhina, Zinkovskaya, Katermina, Shershneva 2016; Zheltukhina, Vikulova, Mikhaylova, Borbotko, Masalimova 2017; Zheltukhina, Mouzykant, Barabash, Ponomarenko, Morozova, Mori 2017, etc.). The information providers include educational systems (knowledge, myths), religions (myths, faith), propaganda, advertising, different cultures, and, in the first place, of mass nature (myths, messages). The language inherent to the mass media revives socio-political communication, arranges the movement of knowledge, myths, emotional upheaval, volitional affection within the field of social time and space (Sokolov 1996: 4). The combination of three worlds exercises effect on a person within the political media scene: a real, an informative (individual memory) and a symbolic (social memory). The weight of the event is described in terms of press accounts (Pocheptsov 2001). We are going to observe in this article, in more depth, the affecting model within the "person - political media scene" system, and define the basic markers of the affecting model in the political media communication.

\section{Methodological bases and research methods}

Methodological basis of our work is the system approach including system and complex, systemic-structural and systemic-functional approaches. The purpose and problems of the research have defined the choice of methods of the analysis. In work such research procedures as hypothetical-deductive method, inductive method, descriptive and comparative method, definition analysis, elements of cognitive interpretation (including frame approach to the analysis of the political metaphor, technique of cognitive scenarios and neurolinguistic, cognitive mapping, analysis of cognitive complexity of texts) are used. Besides, in our research content analysis methods were applied to identification of the substantial party of texts of mass media. The discourse analysis, studying structure and units of a discourse, basic of which is the speech act, and the integrated approach to the analysis of mass media texts consisting in studying of their semantics, pragmatics, syntactics with use of the component, contextual and stylistic analysis were realized.

\section{Results and discussion}

Different communicative problems of our time are discovered in the process of revealing the markers of the affecting model in the current political media communication. A major problem of the contemporary political mass media language is the challenge of the semantic ambiguity that facilitates the impact of an addresser on an addressee. The semantic ambiguity of the political media discourse is a

XLinguae, Volume 10, Issue 4, October 2017, ISSN 1337-8384, eISSN 2453-711X 
consequence of the following factors.

The semantic factors of the political media language comprise:

1) abstractedness and wideness of knowledge: the wideness of abstract words interpretation without clarifying definitions (democracy instead of the parliamentary democracy, process, phenomenon, mission, freedom, justice, etc.) because of its referential uncertainty;

2) meaning complexity caused by the denotation complexity: identification of sets of ideas that are distant from the direct experience of the individual due to the complexity of the extra-linguistic reality (default, impeachment);

3) a smudgy semantic outline of the words of gradual semantics: the lack of stark difference in the marking of socio-political guidelines according to the scale (retrogressive - conservative - liberal-progressive - radical");

4) the symbol relativeness or the ideological polysemy: the use of the same words by the exponents of diverse ideologies to designate sundry concepts, that is, the dependence of the nomination selection on the speaker's position (the same idea is reactionary and liberal); a solidarity of political media evaluations that emphasizes the dominance of the affective-evaluation component over the informative one.

The pragmatic factors of the political media language comprise:

1) inducement, impact: appropriation of linguistic symbols and the definition of their meanings, induction of the desired response from the addressee;

2) manipulative capability by means of ambiguity strategies: a) blooming (fudging of undesirable information), b) mystification (suppression of truth, intentional false representation), c) depersonalization (anonymity, obscuration of responsibility);

3) saving a reputation: suppression of ignorance, incompetence of the addresser through the use of abstract or indeterminate expressions, permitting, if necessary, the denial of the said;

4) conflict-free nature of communication: reasonable, neutral attitude by ambiguity creation when debating controversial issues, promoting caution exercising, smoothing over the differences between communicants, as far as the addresser is ready to sacrifice the understanding distinctiveness in order to increase confidence and gain the sympathy of the addressee (Hamilton, Mineo 1998: 6);

5) activity uncontrollability: ambiguity of contextual notions in program texts, speeches, etc., which impedes the effectiveness of the monitoring of commitments execution, allowing the addresser to tack, to subject its activity to the moral regulations of the situational ethics (Kljucharev 1995: 214).

An institutional nature of the political media communication realizes an inadequate reference as a semiotic mechanism of the semantic ambiguity. The following sorts of referential deviation are differentiated: wide - the correlation of a word with an excessively wide range of referents; abstract - the correlation of a word with an abstract referent; ambiguous - the correlation of a word with a referent which is treated in different way; unknown - the correlation of a word with an unidentified referent; extraneous - the correlation of a word with an "alien" referent; inexistent referentiality - the correlation of a word with an inexistent referent (Kljuev 1996: 215). Contemporary political media texts support the conclusions of E. I. Shejgal that the first three sorts of referential deviation are related to the semantic factors of the semantic ambiguity. The focus on an inexistent or "extraneous" referent, a selfreferentiality (Baudrillard 1981) explicates the phantom nature of a sign, existence of lexical phantoms as words without denotation, the real subject of denomination (Normann 1994). The link to an unidentified referent points to the esoteric nature of a sign (Shejgal 2000). The institutional character of the political media discourse permits the addressee to accept as reality the political, economic, social and other fantasies (real images, mediated, interpreted) that are produced and broadcasted by the communicative intermediaries - politicians and journalists. An institutional character 
of the mass media language is correlated with the leading pragmatic interest principle (the information should be interesting, contain new, unheard information) and bears a hypothetical nature as a prognostic value of the communication (the addresser implements prognostic activities that is being programed consciously), is supported by stereotypes and myths, producing different images.

A phantom nature of the political media discourse is comprised of mythological and literary (the symbols of fictional creatures), conceptual (the terminology of faulty scientific concepts), ideological phantoms (denomination of social utopias, illusions, etc.) (Normann 1994: 53; Chizh, Slyshkin, Zheltukhina, Privalova, Kravchenko 2016). The phantom nature of denotations brings forth mythologemes in the sign space of the media discourse, as well as the category of predictability, which refers to the interpretation of the content of various kinds of statements.

Fideistic nature as a stipulation for the media phantom existence is conditioned by irrationality, drawing on subconscious. Political media influence in the contemporary society is forwarded to emotions and subconscious, but not to intelligence, sequential thought, when the suggestive point dominates over the rational one and the success of communication is stipulated by winning the sympathy and trust of the addressee.

Esoteric or cryptographic nature of the political media discourse depends on the degree of its mythological character. The myth includes a mystery, an enigma, presents an expectation of a miracle, a belief in the super-naturality, the generation of an illusory consciousness. Esoteric nature also depends on the media institute, its political and other commitment, interests and objectives. The downside of the esoteric nature is the hypothetical character, which is purposely enclosed to the mass media reports.

Stereotypes are the regulators of social relationships. They are characterized by the mentality saving, defense of own behavior, the satisfaction of aggressive trends, the group stress exit strategy, the imprecision, the falsehood, the emotional-evaluative character, the relative resilience. The received earlier information has a greater impact on the category creation in comparison with denial of this information. Therefore, the media actively use various pseudo sensations, reprimands, slanders supported by stereotypes (sudden vanishing of authority, etc.). The impact on the addressee reaches the extent of the suggestion and generates prejudices that are caused by "namecalling", crude, contemptuous style of upbringing regarding other persons, sudden childhood emotional trauma in the interacting process with "aliens". Prejudices are pervasive and resistant, because, like stereotypes, they have a cost-effective way of thinking, enduring by virtue of conformism and fanaticism, are activated by the trait anxiety of the society and the danger to the sense of security.

The constancy principle in the information perceiving operates in the media discourse: the addresser interprets the media stimuli in conformity with its already established provisions and expectations (Elder, Cobb 1983). Socio-political attitudes compensate for the cognitive deficiency through modeling the addresser's response to the familiar and strange, unclear socio-political situations and by means of minimizing its risks and hazard (Diligenskij 1996: 156). By virtue of the results of the examination of the relationship between the main components of the person's socio-political attitudes (cognitive, axiological, emotional) carried out by the G.G. Diligenskij the ratio analysis between the cognitive and affective components of socio-political attitudes in the mass media is presented:

1) the typology of public systems (capitalism - socialism, democracy totalitarianism, free society and others) - complacency, conformity, fatalism, moderate criticism, non-conformism, dissatisfaction, protest, radical negativism;

2) the principles governing socio-economic and socio-political relations - love - hate, aversion; enthusiasm, passion - disregard; confidence - disbelief, fright, horror;

XLinguae, Volume 10, Issue 4, October 2017, ISSN 1337-8384, eISSN 2453-711X 
3) the relationship between a person and society, the person's rights and dignity - the sense of dignity - abjection, protection - helplessness, freedom personal dependence;

4) the stability level of the macro-economic and socio-political situation represents the level of psychological apprehension regarding the crucial problem of society;

5) the social and group society structure, inter-ethnic relations the emotional intelligence of the representatives of own and other social and ethnic groups: amicability, peaceful disposition - animosity, aggressiveness.

The components in question find expression in different intensity degree in the following media discourse genres (Zheltukhina 2003; Zheltukhina, Zinkovskaya, Katermina, Shershneva 2016):

critical analytics (topical analytic article, op-ed column, news and analytic broadcast, pamphlet, feuilleton, joke, nonfiction/feature/cartoon film);

public speech (inaugural message, appeal to the public, to the Federal

Assembly, State Duma, Congress, Senate, Bundestag, business elite, cultural luminaries, sports elite, policy speech, meeting report, public rally speech, etc.);

voting (elections, referendum, voting in the studio during talk shows, in the Duma, etc.);

informational announcement (lead article, briefing note, news, broadcast (from convention, public rally, exhibitions, presentations, from the courtroom, terrain of attack, etc.), flyer, graffiti, scandal);

dialog (interview, press conference, radio debates and televised debates, talk show, round table, press discussion, internet discussions, behind-thescenes discussion, non-public meeting, negotiations, official correspondence);

feedback (telegrams, letters, petitions, electors' mandate, addressee's calls to the studio);

document (presidential edict, legislative language, communiqué).

All the above confirms that the cognitive component mirrors the reality of the world of external objects and situations in the psyche, the value component - a person's attitude to this reality supported by the perception of something proper, desirable, the affective component - the true value of the attitudes in the psychological structure of a person: an attitude without a distinct emotional component is usually "weak" and does not play a significant part in the individual's motivation and behavior (Diligenskij 1996: 187). The correlation between the informative aspect and phatics, expressiveness, emotional breadth, suggestiveness differs depending on the genre of the mass media discourse genre. The genre of the ceremonial communication (e.g. inaugural message, valedictory President's speech) (Campbell, Jemieson 1986) relates to the most phatistically oriented genres on the media scene. The televised debates bear the ceremonial character as well, as their organization confirms the availability of democracy in society, the result of which is the assertion by communicants of the state's problems solvability, the normal functioning of institutions and the sovereignty of people (Herbeck 1994).

The television and radio broadcasts of Parliament proceedings bring this genre of political discourse to a qualitatively different level of the media discourse, as the interested addressee is coming into being, apart from the deputies in the hall - it is the electorate. Of course, the informative aspect should prevail over the expressiveness, as opposed to a public rally, which is characterized by predominance of expression and phatics but not an informative aspect. The analysis of transcripts and video recordings of the Parliament proceedings in Russia, Germany, the United States, Great Britain, France relating to the last few years has demonstrated that the correlation between the informative aspect and emotiveness/expressiveness depends on the discussion topic (Zheltukhina, Krasavsky, Slyshkin, Ponomarenko 2016). Informative aspect is obviously prevalent in the course of routine legislation, 
nevertheless, when dealing with purely political issues (such as the budget, the new prime minister appointment, the displacement of the Prosecutor-General, the military actions, etc.), the agonal nature of the political media discourse comes to prominence and the informative aspect yields a seat to expressiveness. Accordingly, where the way is paved for emotiveness/expressiveness, the suggestiveness is generally successful, depending on the objective set by the addresser.

Thus, it can be supposed, extending the idea of E. I. Shejgal, regarding the informativeness/ emotiveness/ expressiveness lines (Shejgal 2000), that extended variation of "informativeness/emotiveness/expressiveness/efficiency/suggestivity" is conditioned not only by the genre but also by the media discourse function, which dominates in a particular discourse event. In addition, the following functions of the political media discourse are highlighted, defined by the human behavior on the modern political media scene according to the "way of dealing with information flows" criterion:

planning by the media addresser of mass information flows involving representatives of various frameworks of reference;

editing by the media addresser and by the media addressee of the texts received, with due consideration of civilized textual communication norms;

structure planning of macro texts on the basis of mini-texts by the media addresser (newspaper or magazine issue, radio program or television broadcast);

- $\quad$ reproduction of mini and macro-texts by the media addresser.

Reciprocity of the mass media with an addressee represents the interaction of subjects on the political media scene. The political media discourse presents an activity and its product that is consumed by that subject which acts as an object of the mass media impact in the political field. The main objective of the information generation is primarily to address the managerial challenges of changing social, economic, and political realities. Herewith, such contradictory tendencies, as the association with the state authorities and independence on power, are pursued in the political media discourse.

Currently there has been observed a saturation of the mass information flows of society with materials including a variety of knowledge, regulations and values. In this way, an opportunity emerges for competition and the choice between moral and spiritual quest of people and their contrary outpourings, thus developing the society's mass consciousness and preserving the required level of its continuity, of common significance. The choice of material is very broad: starting from news, speeches of social and political activists in the mass media, demonstrations of a variety of documentary, fictional works to games and advertising, which exercise not only informative but also hedonistic (pleasure) and suggestive functions.

By concentrating a variety of creative works of different kinds, the political mass media use it as components to assemble new and new elements of an integrated product, enabling the addressee to generate a moving, volume, polyphonic information picture of the social and economic and political realities at any given point, a world's map, including a scheme of the society's values. This scheme may be more or less consistent with reality, but it enables the addressee to see which way the wind is blowing a little confidently, ponder in this regard, and correct its decisions and actions. The degree of reliability of the operation of the mechanisms of selfregulation of society, affecting the mechanisms of public administration, directly depends on the degree of its correspondence to reality and of its diversity. The farther it is from reality, the more improvised it is, the more is the degree of possibility of failures in either mechanism, the greater is the danger to society.

Mass media in the political field do not simply generate the mass information flows; they also stipulate the effects that are caused in society by consumption of their

XLinguae, Volume 10, Issue 4, October 2017, ISSN 1337-8384, eISSN 2453-711X 
product. If at present the demonstrations of violence as a means of problem solving on the television screens becomes dominating, even though there are other opportunities in life, it can lead to the concept that force will dominate among the values of the mass consciousness (Lazutina 1999: 55-57).

The projection of the results of examination of the consumer behavior (USA) on the political media discourse suggests some assumptions regarding the behavior of the political media consumers. It is possible to mark out the following characteristics of the addressee (Zheltuhina 2003):

1. Impulsivity. The addressee commits most of its actions impulsively, i.e. inadvertently, under the influence of a sudden inducement, impulse (results of recent public rallies in Russia in 2017).

2. Conventionalism. Mass media do not alter the addressee's convictions regarding its preferred modus of action. The addressee selects such a direction of action that is constantly mentioned in the mass media if an unusual, new situation for it is created.

3. Transogenicity. J. Vicary has revealed that a person who looks at the goods he/she is going to buy, will stop, cease to blink and swallowing saliva, his/her breathing slows, the pupils expand, the eyes losses focus, i.e. he/she falls into the hypnotically trance. The eyes of a normal person blink 32 times a minute, in the state of intense excitement, stress - 50-60 times, and in a relaxed state up to 20 times maximum. In the process of the goods selection, the number of flashing drops to 14 (Mokshantsev 2009). Assumptive, a person, who hears and sees in a political media discourse the points close and familiar to him/her, also falls into a state of hypnotic trance.

4. Associativity. The addressee tends to identify himself with the protagonist of the printed text plotting or film if it is adequately picked as an audience, listener, reader, or internet user of the mass media products. Put it otherwise, the identification mechanism operates. A real person accepts a hero's behavioral pattern, its discourse, and when confronted with a similar situation, he/she behaves in the same way as seen or painted in the imagination character (photo sessions on the site of the terrorist act of 2017; flowers, candles, soft toys at the site of terrorist attack; large-scale protests with arson and destruction, etc.).

Unfortunately, it must be noted that, to date, the political mass media force to the addressee a negative map of the world, either far from reality or too close to reality, which is contributing to the failure in public mechanisms. Ideological pluralism, disengagement in political and business media groups, new economic provisions that have altered the sign of ownership and the mass media dependence to the opposite, the emergence of shocking sexual motives, elements of violence on the screens, the emergence and rapid replication of the publications new for Russia of the end of XX beginning of XXI centuries - yellow sheets and elite press and magazines, etc. may give rise to this.

\section{Conclusion}

So, issues regarding the means of creation, storage and use of the information and the ways it affects the addressee in the media discourse are recognized relevant for the contemporary communicative research. The mechanism of impact, suggestiveness and cognitive processes are more fully disclosed in the modern political media environment when the interpretation process intends to capture the information from previous fragments of the political media discourse. This course requires addressing a number of problems related to the implementation of mental representations between the addresser and the addressee and their interrelationship in the political media discourse, establishment of contextual links, their storage and use, and their operation. The executed research has demonstrated that the political language of the mass media reveals the peculiarities of linguistic consciousness, mentality, individual and mass 
speech behavior reflecting the manifestation the institutional, stereotypical and mythological markers of the reactive model in the contemporary political media communication. The mass media, by means of suggestive psycho-technology on the media scene, govern people who act often without being aware of the motives behind their actions. In the apprehension of suggestive information, the addressee's consciousness is switched on by a keyword, symbol, sign, etc., and defines the behavior of the individual on the political media scene. Except for the basic "text" channel, which includes a message, a "collective unconscious" channel manages the communication and behavior of all participants in the interaction. Herewith, neither the addresser nor the addressee, in some cases, is aware of mental programming through the implementation of the reactive model in the political media communication.

\section{Bibliographic references}

BAUDRILLARD, J. 1981. Simulacres et Simulation. Paris: Galilée. ISBN 978-27186-0210-3.

CAMPBELL, K.K. - JEMIESON, K.H. 1986. Inaugurating the Presidency. Form, Genre and the Study of Political Discourse. Columbia (S. Car.): Univ. of S. Car. Press, pp. 203-205. ISBN 0872494683, 9780872494688.

CHIZH, N.V. - SLYSHKIN, G.G. - ZHELTUKHINA, M.R. - PRIVALOVA, I.V. KRAVCHENKO, O.A. 2016. Concept "Medical Museum" as a Sociocultural Phenomenon. International Journal of Environmental and Science Education, 11(17), pp. 10529-10538. eISSN 1306-3065.

DILIGENSKIJ, G.G. 1996. Sotsial'no-politicheskaya psikhologiya. M.: Nov. shkola. ISBN 5-02-013558-5.

ELDER, C.D. - COBB, R.W. 1983. The Political Uses of Symbols. N.Y.: Longman. ISBN $0582283922,9780582283923$.

FISKE, J. 1993. Television Culture. L., N.Y.: Routledge. ISBN 0-415-03934-7.

GARSIYA-KASELES, K. 2015a. Radical, Right movement of Spanish Confederation of Autonomous Right (CEDA) in Spain in the context of political linguistics. (The early XX century). Science and Education. Munich, Germany, March $19^{\text {th }}-20^{\text {th }}, 2015$, pp. 235-239. ISBN 978-3-941352-21-6.

GARSIYA-KASELES, K. 2015b. Spanish antroponymy on the example of personalities of "The generation of 98", Ceteris Paribus, 1, pp. 69-74. ISSN 2411$717 \mathrm{X}$

GARSIYA-KASELES, K. 2015c. Spanish Fascism as a paradigm of historical development. European Science and Technology. Munich, Germany, December $24^{\text {th }}-$ $25^{\text {th }}, 2015$, pp.15-20. ISBN 978-3-941352-44-5.

HACKER, K.L. 1996. Political Linguistic Discourse Analysis. The Theory and Practice of Political Communication Research. N.Y.: State Univ. of N.Y. Press, pp. 28-55. ISBN 10: 0791429008. ISBN 13: 9780791429006.

HAMILTON, A. - MINEO, P.J. 1998. A Framework for Understanding Equivocation. Journal of Language and Social Psychology, 17 (1), pp. 3-35. ISSN: 0261-927X. Online ISSN: 1552-6526.

HERBECK, D.A. 1994. Presidential Debate as Political Ritual: Clinton vs. Bush vs. Perot. Bill Clinton on Stump, State and Stage: The Rhetorical Road to the White House. Fayetteville: Univ. of Arkansas Press, pp. 249-272. ISBN 1557283656, 1557283729.

KARPUKHIN, O. - MAKAREVICH, E.H. 2001. Formirovanie mass: Priroda obshhestvennykh svyazej i tekhnologii «pablik rilejshnz»: Opyt istorikosotsiologicheskogo issledovaniya. Kaliningrad: FGUIPP; YAntar. skaz. ISBN 5-7406-

XLinguae, Volume 10, Issue 4, October 2017, ISSN 1337-8384, eISSN 2453-711X 
0447-8.

KHRULYOVA, A.A. - SAKHIEVA, R.G. 2017. Forming of Informational Culture as a Necessary Condition of the Level Raising of Higher Education. In: Man In India, vol. 97, n. 15, pp. 211-225. ISSN: 00251569.

KLJUCHAREV, G. A. 1995. Jazykovaja dejatel'nost' i politicheskij imidzh. Obnovlenie Rossii: trudnyj poisk reshenij. Moskva: RNISiNP, 3, pp. 211-216.

KLJUEV, E.V. 1996. Fatika kak predmet diskussii. Pojetika. Stilistika. Jazyk i kul'tura. Moskva: Science, pp. 212-220. ISBN ISBN 5-02-011248-8

KONGY. - KAYUMOVA, L.R. - ZAKIROVA, V.G. 2017. Simulation Technologies in Preparing Teachers to Deal with Risks. In: EURASIA Journal of Mathematics, Science and Technology Education, vol. 13, n. 8, pp. 4753-4763. ISSN: 13058215, 13058223.

LAZUTINA, G.V. 1999. Professional'naya ehtika zhurnalista: Uchebn. posobie po zhurnalistike. M.: Aspekt Press. ISBN 978-5-7567-0612-3.

LEVINA, E.Y. - MASALIMOVA, A.R. - KRYUKOVA, N.I. - GREBENNIKOV, V.V. - MARCHUK, N.N. - SHIREV, D.A. - RENGLIKH, K.A. - SHAGIEVA, R.V. 2017. Structure and Content of e-Learning Information Environment Based on Geo-Information Technologies. In: EURASIA Journal of Mathematics, Science and Technology Education, vol. 13, n. 8, pp. 5019-5031. ISSN: 13058215, 13058223.

MASALIMOVA, A.R. - LEVINA, E.Y. - PLATONOVA, R.I. - YAKUBENKO, K.YU. - MAMITOVA, N.V. - ARZUMANOVA, L.L. - GREBENNIKOV, V.V. MARCHUK, N.N. 2017. Cognitive Simulation as Integrated Innovative Technology in Teaching of Social and Humanitarian Disciplines. In: EURASIA Journal of Mathematics, Science and Technology Education, vol. 13, n. 8, pp. 4915-4928. ISSN: 13058215, 13058223.

MOKSHANTSEV, R.I. 2009. Psikhologiya reklamy: Uch. pos. / Nauch. red. M.V. Udal'tsova. M.: INFRA-M, Novosibirsk: Sibirskoe soglashenie. ISBN ISBN 978-516-000135-7, 978-5-8479-0014-0.

NORMANN, B.JU. 1994. Leksicheskie fantomy s tochki zrenija lingvistiki i kul'turologii. Jazyk i kul'tura: 3-ja mezhdunar. konf. Kiev: UIMO, pp. 53-60.

POCHEPCOV, G.G. 2001. Teoriya kommunikacii: ucheb. posobie. M.: Vakler. ISBN 5-87983-101-9, 966-543-062-9, 966-543-048-3.

PONOMARENKO, E.B. 2013a. Leksiko-frazeologicheskie edinicy v russkih novostnyh tekstah. Russian Philology, 32, pp. 48-58. ISSN 2231-1564.

PONOMARENKO, E.B. 2013b. Linguistic Manipulation Devices. GISAP: Philological Sciences, 1, March, pp. 62-65. ISSN 2053-1532, eISSN 2053-1540.

PONOMARENKO, E.B. 2013c. Strukturnye i semantiko-stilisticheskie osobennosti tekstov anglijskih i russkih informacionnyh soobshchenij. GISAP: Philological Sciences, 1, March, pp. 59-62. ISSN 2053-1532, eISSN 2053-1540.

SHEJGAL, E.I. 2000. Semiotika politicheskogo diskursa. Volgograd: Peremena. ISBN 5-88234-394-1

SLYSHKIN, G.G. 2007. Kontsept lichnosti kak ehlement lingvokul'turnoj istoriosfery (na materiale kontsepta «Talejran»). Ethnohermeneutik und kognitive Linguistik / Hrsg. von R.D. Kerimov. Landau: Verlag Empirische Pädagogik, pp. 81-88. ISBN 978-3-937333-59-5.

SOKOLOV, A. V. 1996. Vvedenie v teoriyu sotsial'noj kommunikatsii. SPb.: SPbGUP. ISBN 5-7621-0020-0.

ZHELTUHINA, M. R. 2003. Tropologicheskaya suggestivnost' massmedial'nogo diskursa: o specifike rechevogo vozdejstviya tropov v yazyke SMI. Moskva Volgograd: IYA RAN, VF MUPK. ISBN 5-88234-568-5.

ZHELTUKHINA, M.R. 2014. Interkulturelle semantische und pragmatische Parallelen im modernen Mediendiskurs: der funktionale Aspekt. Interkulturalität unter dem Blickwinkel von Semantik und Pragmatik / Csaba Földes (Hrsg.) Beiträge zur 
interkulturellen Germanistik; Bd. 5: Sammelbände. Tübingen: Narr. S. 257-275. ISBN 9783823379058.

ZHELTUKHINA, M R. 2015. Institutional, Stereotypical and Mythological Media Markers of Modern Society. Biosciences Biotechnology Research Asia, April, 12 (1), pp. 913-920. ISSN 0973-1245, eISSN 2456-2602.

ZHELTUKHINA, M.R. - KRASAVSKY, N.A. - PONOMARENKO, E.B. ALESHCHANOVA, I.V. - PAVLOV, P.V. 2016. Political Facebook Posts Using Ideological Symbols for Media Image Designing of Russia as Enemy. International Journal of Environmental and Science Education, 11(18), pp. 12005-12013. eISSN 1306-3065.

ZHELTUKHINA, M.R. - KRASAVSKY, N.A. - SLYSHKIN, G.G. PONOMARENKO, E.B. 2016. Utilitarian and Aesthetic Values in the Modern German Society (Through the Example of Print Media Advertisements). IEJMEMathematics Education, 11(5), pp. 1411-1418. ISSN 2468-4945.

ZHELTUKHINA, M.R. - MOUZYKANT, V.L. - BARABASH, V.V. PONOMARENKO, E.B. - MOROZOVA, E.V. - MORI, S. 2017. Russian and Japanese Younger Generations in Search for a New Media Product. Man In India, 97 (3), pp. 223-236. ISSN: 0025-1569.

ZHELTUKHINA, M.R. - SLYSHKIN, G.G. - PONOMARENKO, E.B. BUSYGINA, M.V. - OMELCHENKO, A.V. 2016. Role of Media Rumors in the Modern Society. International Journal of Environmental and Science Education, 11(17), pp. 10581-10589. eISSN 1306-3065.

ZHELTUKHINA, M.R. - VIKULOVA, L.G. - MIKHAYLOVA, S.V. BORBOTKO, L.A. - MASALIMOVA, A.R. 2017. Communicative Theatre Space in the Linguistic and Pragmatic Paradigm. XLinguae, Volume 10, Issue 2, April 2017, pp. 85-100. ISSN 1337-8384.

ZHELTUKHINA, M.R. - VIKULOVA, L.G. - SEREBRENNIKOVA, E.F. GERASIMOVA, S.A. - BORBOTKO, L.A. 2016. Identity as an Element of Human and Language Universes: Axiological Aspect. International Journal of Environmental and Science Education, 11(17), pp. 10413-10422. eISSN 1306-3065.

ZHELTUKHINA, M.R. - VIKULOVA, L.G. - SLYSHKIN, G.G. - VASILEVA, E.G. 2016. Naming as Instrument of Strengthening of the Dynastic Power in the early middle Ages (France, England, Vth - XIth Centuries). International Journal of Environmental and Science Education, 11(14), pp. 7195-7205. eISSN 1306-3065.

ZHELTUKHINA, M.R. - ZINKOVSKAYA, A.V. - KATERMINA, V.V. SHERSHNEVA, N.B. 2016. Dialogue as a Constituent Resource for Dramatic Discourse: Language, Person and Culture. International Journal of Environmental and Science Education, 11(15), pp. 7408-7420. eISSN 1306-3065. 
Words: 5231

Characters: 37575 (20,9 standard pages)

Associate Prof. Elena Borisovna Ponomarenko, PhD.

Faculty of Philology

Peoples' Frendship University of Russia

Mikluho-Maclay 10/2

117198 Moscow

Russia

ponomar_elena@mail.ru

Prof. Marina Rostislavovna Zheltukhina, DrSc.

Institute for Foreign Languages

Volgograd State Socio-Pedagogical University

Lenin Prospect 27

400066 Volgograd

Russia

zzmr@mail.ru

Prof. Gennady Gennadievich Slyshkin, DrSc.

Institute of Law and National Security

Russian Presidential Academy of National Economy and Public Administration Vernadsky Prospect, 84/2, 6

119606 Moscow

Russia

ggsl@yandex.ru

Assistant Prof. Liudmila Alekseevna Borzykh

Faculty of Philology

Peoples' Frendship University of Russia

Mikluho-Maclay 10/2

117198 Moscow

Russia

borzykh_la@yahoo.com

Associate Prof. Conchita García Caselles, PhD.

Faculty of Philology

Peoples' Frendship University of Russia

Mikluho-Maclay 10/2

117198 Moscow

Russia

konchitag@mail.ru 